DOI: https://doi.org/10.46991/AFA/2021.17.2.027

\title{
ON SEVERAL RECURRENT THEMES AND CONCEPTS IN SCOTTISH BALLADS
}

\author{
Arpineh Madoyan* \\ Yerevaan State University
}

The present article seeks to study the concepts of "love" and "homeland" from linguistic and cultural perspectives. Within the frames of the article an attempt is made to elucidate these concepts in Scottish ballads and media. The article also dwells upon the inherent nature of the aforementioned concepts as underlying units of Scottish culture since concepts as such reflect the mental activities of language speakers. The concepts of "love" and "homeland" embody crucial values and images common to any linguo-culture. The linguo-cultural analysis of factual data taken from folk texts (Scottish ballads) and media discourse (articles) sheds light upon not only the lexical actualization but also modern perception of the given concepts. The choice of the material is conditioned by the necessity to highlight their diachronic evolution and their importance in contemporary research. A special reference is made to the media coverage of the Scottish Independence referendum, which illustrates Scots' attitude towards their ethnic identity and their country as a whole.

Keywords: Scottish ballads, Scottish Independence Referendum, concepts, love, homeland, linguo-culture.

\section{Introduction}

Ballads, being the linguo-cultural reflection of a nation's oral traditions are handed down from generation to generation. It is hard to overestimate the significance of ballads in the study of the language picture of the world of a nation concerned. Ballads are seen as a means to uncover the inherent nature of identity of people for their plot usually develops around such fundamental concepts as homeland, freedom, honour, friendship, love, happiness and others. These concepts account for the formation of national cultural values and reflect the culture-bound attitudes toward them. This is particularly important for the 
interpretation of the fundamental linguo-cultural and national concepts and drawing parallels across cultures. It is widely argued that the fundamental concepts embody the typical features of national mentality (Sternin, 1984; Maslova, 2004; Karasik, 2004; Popova \&Sternin, 2007 and others).

The last decades have seen a certain degree of decline of interest in reading ballads, which could be explained by the complexity of the genre. However, the genre has not lost its relevance as an object of multilayered research from literary, cultural, historical and ideological perspectives. Being a combination of lyrical, epic and dramatic dimensions, ballads remain a reliable source for investigating the history and culture of a nation along with the experiences of people and their emotional development. This aspect makes ballads a valuable source contributing to the increase of the cultural knowledge and promoting intercultural communication.

The present paper aims at studying of several central themes in Scottish ballads and suggests looking at the concepts love, homeland and freedom as the most pronounced and recurrent ones. The methodological framework is built on contextual and conceptual methods of analysis. While the contextual method is used to discuss the figurative use of language units, the conceptual method aims to describe the concepts under study and trace their culture-bound interpretations. The choice of the mentioned concepts, specifically the concepts homeland and freedom, is not by chance. As will be shown in the final part of the paper, the concepts remain valid for investigating their influence on the current social, cultural and political developments.

\section{Ballads as a special genre of folk literature}

Ballads are oral transmission of songs and stories that are subjected to modifications conditioned by the storyteller's intentions, regional peculiarities and historical context. As G. Gerould terms it: "Defined in simplest terms the ballad is a folk song that tells a story" (Gerould, 1957, p. 3). In his studies Gerould emphasizes that ballads are universal cultural entities that are found in almost every nations' oral tradition. He emphasizes that all ballads are of situational nature in which the action unfolds in a single episode: "Their structure is as fundamentally different as is their style; the compressed and centralized episode is their unit (ibid., 1957, p. 6)". Dwelling upon the peculiarities of a ballad as a genre in literature, it should be stressed that the narrative of the latter is endowed with certain dramatic undertones. The aforementioned dramatic feature of ballads is accounted for by the fact that 
actions and situations here are introduced in a dramatic way. Another peculiarity of ballads consists in the storyteller's impersonal attitude to the events of the narrative, as the narrator's opinions and beliefs are mainly of secondary importance. Even if the formulaic use of "I" is encountered, this may owe to the fact that the narrator wants to make his narrative closer to the audience. The impersonality, however, does not imply neutral or even emotionless attitude on part of the storyteller and his/her audience. Quite the contrary, both parties involved do sympathize with the heroes' misfortunes, lost love and homeland. As G. Gerould contends "objectivity of approach to ballad themes is certainly one factor helpful to a definition of the genre" (Gerould, 1957, p.10). Summing up the inherent peculiarities of ballads, it can be stated that they are merely folksongs, focusing on an important situation; the unfolding narrative that describes the events is impartial and unbiased, with almost no comment. The in-depth study of ballads as pieces of folklore may allow us to surmise that they are immensely valuable as they reflect the racial memory as well as customs and beliefs of any nation.

\section{The aesthetic and antiquarian value of ballads}

At the end of the $18^{\text {th }}$ and during the $19^{\text {th }}$ centuries, the scholars came to appreciate the aesthetic and antiquarian value of ballads as constituents of folkpoetry. In this connection, we cannot but mention Victorian Francis J.Chide's efforts to collect every possible variant of every popular ballad as well as English collector Th. Percy's collection that mainly comprised Scottish ballads. The poetic features of ballads fascinated T. Percy as in his view the latter were true remnants of ancient British poetry. Through centuries antiquarians started to find a connection between ballads and culturally national narrative. T. Percy opposed this tendency, arguing that ballads were relics of ancient British poetry which had equal standing with the classics. However, the culturally nationalistic Scottish collectors had other thoughts concerning the matter. James Hogg, David Herd, Robert Burns, Walter Scott, Robert Jamieson described Percy's ballads as gems of Scotland. W. Scott's collection "Minstrelsy of the Scottish Border" consisted of the same ballads as found in Percy's collection. Nevertheless, W. Scott included other variants of one and the same ballad, introducing their geographical, historical and cultural origins.

J. Hogg, another $19^{\text {th }}$ century collector, emphasized that ballads were living entities as many real people were singing them. In his view, the ballad must be 
sung for it to be authentic as printed ballads are devoid of the same aesthetic value as the ones sung by people.

In terms of their aesthetic value, ballads cannot be defined as a form of simple poetry as they embody oral art of people who, driven by their imagination, unconsciously created truly precious pieces characterized by spontaneous ingenuity. In this connection, it should be noted that ballads are not to be seen as individual specimens, but rather international phenomena typical of European folk in general (Gerould, 1957). In terms of their thematic peculiarities, ballads consist of romantic and heroic narratives which are identified by intense dramatic situations where certain rhetorical devices like parallelism, hyperbole and refrains can be identified. Their use endows the verse with more intense emotive charge (ibid.).

One of the recurrent concepts in Scottish ballads is the concept love. The concept is a multifaceted phenomenon and, as such, it is studied from various perspectives. V. Kolesov sees the concept as an integral part of national mentality and has got both linguistic and cultural values (Kolesov \& Pimenova, 2012), while A. Wierzbicka adheres to the metalinguistic approach to the study of love as a concept (Wierzbicka, 1992). In S. G. Vorakachev's view, love is a "teleonomical (brought about through human or divine intention) concept" and is the essence of an individual's life, it transcends the possible limits of existence in pursuit of unity with the absolute Goodness (Vorkachev, 2003, p. 27). In this research, we adhere to the premise that love is a linguo-cultural entity which reflects the specifics of national mentality. Thus, the analysis of the aforementioned concept in ballads will enable us to gain some insight in the Scottish perception of "love" as a linguo-cultural concept. The ballad "The Douglas Tragedy" tells the tragic love story of Lord Douglas and Lady Margaret. Sir Douglas carries Lady Margaret away against her family's will while her father and seven brothers pursue them to save the honor of the family. Douglas mounted her on "a milk-white steed". The innocence of the lady is lexically actualized via the phrase milk white steed, while in contrast Douglas' horse is grey. It is noteworthy, that as the narrative unfolds, the color of Douglas' horse changes, while Margaret still rides the same white steed. Meanwhile Margaret's father and brothers reach them and fight ensues between Douglas and Margaret's family. The outcome of the fight is indeed tragic as Douglas kills her seven brothers "and there she saw her seven brethren slain and her father still fechting sae dear" (Chambers, 1829, p.112). In her attempt to save her father's life Lady Margaret begs for Douglas' mercy, "O hald your 
hand sweet William! For your strokes they are wondrous sair; true lovers I may mony a ane, but a father I can never get mair" (ibid., p.112). Here we witness the heroine's limitless love for her father as she rightly thinks that no lover can replace her father. Their journey is a sorrowful one, as is illustrated in the passage "and they baith went weeping along" (ibid., p.112). Thus it becomes clear that the concept love borders on the concept of sorrow, i.e. love is pain you have to make a sacrifice to attain it. The hardships of finding love are highlighted in the final part of the ballad, when Sir Douglas dies from his wounds and Lady Margaret follows him,

Lord William was buriet in St Mairie's kirk, Lady Maragaret in St Mairies' quier: Out o' the lady's grave grew a bonnie red rose and out o' the knicht's a brier. And they twa met and they twa plett and fain they wad be near. (Chambers, 1829, p.114)

On the lexical level, the tragic nature of love is expressed via the brier, symbolizing the thorny path that one has to take to find love, and rose which is the token of such a sweet and irrational feeling as love.

The ballad "Sweet Willie and Fair Annie" narrates another tragic love story. Willie and Annie love each other, but Willie's mother does not give her consent to their marriage, as she wants her son to marry a wealthier girl and leave Annie: "There are twa maidens in the bouir which of them shall I bring? The nut-brown maid has sheep and kye, and fair Annie has nane"(Chambers, 1829, p. 270). With pain in his heart, Willie abides by his mother's will: "O I sall wed the nut-brown maid, and I sall bring her hame; though peace suld ne'er be us between, till death sinder's again". Thence, Fair Annie attends Willie's wedding.

And when she cam to Marie's kirk in the deas, the licht that cam frae fair Annie enlichtent a' the place. The cleiding that fair Annie had on was sae wi' pearls ower-dune, that whan she cam into the kirk she shimmered like the sun. (Chambers, 1829, p. 273)

Through the analysis of the lexical units of the ballad, it becomes apparent that Annie's love for Willie is magical, she radiates licht (light) and the whole place is enlichtent (enlightened). The simile expressed in shimmered like the sun intensifies the unearthly qualities which Annie is endowed with. In other words, through mapping we can state that love is light; love is sun, love is 
something superhuman. Noteworthy is the fact that, like in the previous ballad, here too "rose" symbolizes love and affection: "Willie had a rose into his hand; he gave it kisses three; and, reaching by the nut-brown bride, laid it on Annie's knee" (Chambers, 1829, p. 274). Annie rejects the flower, emphasizing the ephemeral nature of love and the pain she has to suffer for the sake of love: "Tak back and weir your rose Willie as lang as it will last; for like your love, its sweetness will sune (soon) be gane and past. Weir ye the rose of love Willie and I the thorn o' care"'(Chambers, 1829, p. 276). In the mentioned excerpt, we can see that the concept love is associated with the concept bitterness (thorn is its overt lexical expression). Annie's sadness drives her to death, Willie learns about it in his dream and, being unable to cope with the sorrow, he also dies. Finally, the two lovers are unified in the afterlife.

The tane was buriet in Marie's kirk, the tother in Marie's quier; and o' the tane there grew a birk and out o' the tother a brier. And aye they grew and they drew, as they wald faine be near, and every ane that passed them by said "Thae's been lovers deir! (Chambers, 1829, p. 276)

The final repetition heightens the emotive impact of the message.

\section{Concept homeland and its materialization in ballads}

From a linguo-cultural perspective, "homeland" or as Vorkachov states "this country" may have different expressions on the lexical level and be associated with diverse adjacent concepts. In Vorkachov's opinion, "homeland" as a linguo-cultural concept is essentially an ideological entity since it reflects the people's expectations from the society they live in and their aspirations for creating the ideal social structure. In other words, the concept "homeland" not only represents the self-perception of the ethnos as a bearer of a distinct culture, but also expresses the evaluation of "national characteristics" (Vorkachev et al., 2007, p. 40). In his study, Vorkachov comes to evidence that the British linguocultural specifics seem to be somewhat "void of the concept homeland, country". In his research, he highlights that unlike Russian linguo-culture, where "happiness" is frequently used with "country, homeland", the British seem to be reluctant to find its verbalizations on the lexical level (ibid., 2007). McCrone, discussing such issues as Scottish identity and society, claims that Scotland is more appropriate to be referred to as "country" since it bears a wide range of connotations. According to McCrone, "country" embodies all the 
crucial values and images, and is the "fusion of land and nation" (McCrone, 2005, p. 38).

The study of the Scottish ballads enables us to claim that the Scots' century-long struggle for the "dream" of defeating the rivaling country (England) or shaping their identity is certainly reflected in the Scottish folk tradition. Given the historical context, the border disputes and fights between England and Scotland were of constant nature. The ballad "The Battle of Otterbourne" is based on real historical events when Scottish noblemen invaded England. Earl of Douglas, one of the most distinguished warriors, led the Scottish army. When the Scots reached Newcastle, Percy, Earl of Northumberland tried to stop the Scottish advance. Eventually, Scots won the battle despite the fact that Sir Douglas died. The battle at Otterbourne turned out to be catastrophic for both Douglas and Percy as the former fell in the battle and Sir Hugh Montgomery held Percy captive. As the narrative evolves, Earl Douglas managed to win the fight with Percy. The duel between Percy and Douglas may be interpreted as an ongoing English-Scottish hostility, when one party tries to subdue the other: "He took a lang speir in his hand shod with the metal free; and for to meet the Douglas there, he rode richt furiouslie" (Chambers, 1829, p. 16). In other words, through metonymy the concept of warring countries is expressed. None of the parties is willing to give in for the sake of their country's honor, and one (in this case Douglas) has to die for the cause. Hence, we can infer that the concept homeland is related to the concept "self-sacrifice".

Another historical ballad, "Sir Patrick Spence", narrates the tragic story of Patrick Spence who died, sailing back home. As far as the historical background is concerned, in 1251, by the order of the Scottish King Alexander III, Patrick Spence along with other Scottish noblemen accompanied the king's daughter Margaret to Norway who was married to a Norwegian king. Sir Patrick Spence and all the noblemen drowned on their way back home. The narration of the ballad starts with Sir Patrick's lament over the king's letter in which he ordered Sir Patrick to sail to Norway to accompany Margaret: " $O$ wha is this has done this deed, and tauld the king o' me? To send us out at this time $o$ ' year to sail upon the sea!'”(Chambers, 1829, p. 4)*. The given passage depicts the crew's attempt to return to homeland: "Sir Patrick he is on the sea, and far out ower the faem wi' five-and fifty lords' sons that longed to be at

\footnotetext{
* It should be mentioned that due to the faulty system of navigation it was highly dangerous to sail in the wintertime.
} 
hame" (Chambers, 1829, p. 6). The noblemen's yearning for their homeland, homesickness is exemplified by the phrase "that longed to be at hame". As any piece of folklore, ballads also have some supernatural elements; one may encounter good omens or more commonly bad ones. Moreover, the characters' premonitions are materialized in their dreams. In the ballad about Sir Percy a mermaid is the supernatural force that comes to reassure Patrick, notifying about his return to Scotland:

"Upstartit the mermaid by the ship wi' a glass and a kame in her hand; says, reek about, my merry-men ye are nae far frae land." To which Sir Patrick responds: "Ye lie, ye lie, my bonnie mermaid, sae loud as I hear ye lie; for sin' I hae seen your face this nicht, the land I will never see (Chambers, 1829, p. 6).

The mermaid is the harbinger of the crew's imminent doom, as they will never see land (Scotland) again. In the passage above, the aesthetic impact of the narrative is heightened by the repetition "Ye lie, ye lie". Thus, from the analysis of the contextual and co-textual cues, it can be inferred that unlike the death that awaits the Scottish noblemen, land-homeland is the impossible destination to reach.

\section{A discourse on freedom: from oral tradition to modern times}

Scots have long been searching for their freedom and cherishing the hope for the establishment of a sovereign state. Studies in any aspects of the Scottish culture and history could hardly be complete without considering the phenomenon of identity.

In the late $20^{\text {th }}$ and at the beginning of the $21^{\text {st }}$ centuries, the perception of identity underwent global changes. In this connection, the sociologist Zygmunt Bauman has noted: "If the modern problem of identity was how to construct an identity and keep it solid and stable, the postmodern "problem of identity" is primarily how to avoid fixation and keep options open. In the case of identity, the catchword of modern was creation; the catchword of post-modernity is recycling (Bauman, as cited in McCrone, 2005, p. 150). To put it otherwise, people are in an ongoing quest for their identity in the modern world. In regard to defining Scottish identity, McCrone claims that "being Scottish is simply a device for not being English" (McCrone, 2005, p. 149). Historically, the monarchy, along with geographic specifics in Scotland, shaped a sense of belonging between Highlanders and Lowlanders. Their loyalty to the Scottish 
king and unwillingness to be subjected by the English were the foundations of Scottish identity. The English state's policy and the border wars between Scotland and England were the underlying basis to mould the Scottish as a nation. The awareness of national identity consisted in "Scots" against the eternal "foe".

Historically established circumstances have resulted in the development of a discourse on freedom and on the love of freedom which has enriched the concept with a specific content and attitudes. The latter can be observed in the historical-cultural context by drawing parallels between texts of various genres and created in historically distant periods.

The ballad "Young Douglas" focuses on Douglas' love for his homeland (A Ballad, n.d.). Douglas is not reconciled to Scotland's fate and wants it to regain its sovereignty. For his "rebellious" thoughts he is unfairly imprisoned: "Douglas young they've piiten by in Saughton jail is he. He bide by thae that rob and rape that stude for Scot land free". The analysis of the contextual cues enables us to state that Young Douglas is willing to undergo any hardships and experience any sufferings for his country's sake. As the narrative unfolds, Douglas persists with the idea to see Scotland free from the English rule and is incarcerated again: "Their talk o' freedom's jist a say. As Douglas kens owre weel. He talked o' Scottish libertie. Sae Douglas bides in jail. His crime was that he spak the truth. Anent oor trauchled land. He caad for justice - he'd a hope. Frae English-monied hands.'

The study of the lexical units makes it possible to observe the close connection between the concepts love and freedom as Douglas loses his freedom for Scotland to gain its own. The multiple uses of the lexical units, representing the concept (freedom, liberty) testifies to this. Moreover, Douglas' love is expressed in his proclivity to tell the truth (that Scotland should get rid of the English grip-monied hands), thus, love, hope and truthfulness can be seen as constituents of the concept freedom: "When Douglas tellt them historie's truth. Nae answer could they gie. They pit him by for a twal month I' the war for libertie!"

The discourse on freedom plays a strong and important role in the context of current societal and political developments. In the last decades of the $20^{\text {th }}$ century Scots asserted their "Scottishness" simultaneously, priding themselves on being British. The rise of Scottishness has led to questioning Scotland's membership to Great Britain. The concepts freedom and also independence were widely circulated in press during the 2014 Independence Referendum, a historical event, as the "Yes" or "No" vote would bring about serious implications for Scotland and its people. 
Mitchell states that print media helped shaping a sense of Scottishness in everyday life, as Scots became more aware of the English (Mitchell, 2014, p, 36 as cited in Engstrom, 2019, p. 32). The analysis of the media coverage of the referendum shows that the print media greatly supported pro-union (Dekavalla, 2016 as cited in Engstrom, 2014, p. 32), whereas the online activity was primarily in favor of independence. It should be noted that the given research mainly focuses on how the concepts freedom and independence were expressed in the headlines on the Scottish independence referendum. The Sunday Herald's "Scotland's day of reckoning" features the implicit question: What do Scots really want? From a conceptual perspective, Scotland and Scots are one and the same entity. Here the use of personification testifies to the fact that every Scot is Scotland and it is their duty to vote conscientiously as the verb "reckon" is used to imply it. In the headline, "day" metaphorically stands for both past and future, i.e. Scots had long been waiting for this day and, whatever the result might be, their life ahead would not be the same. Interestingly, the graphic image under the headline may also give us a clue about the paper's view on the referendum. The image of a solitary man standing on the top of the mountain can be interpreted in the following way: Scotland is personified by the solitary manand mountain top represents the sublime goal - the independence. Another headline, "Day of destiny", along with the image of the Scottish symbol thistle, circulated on the front page of the newspaper Scotsman. Once again the use of "Day"testifies to the far-reaching implications of the referendum outcome. "Day" is associated with the historical "past" and the

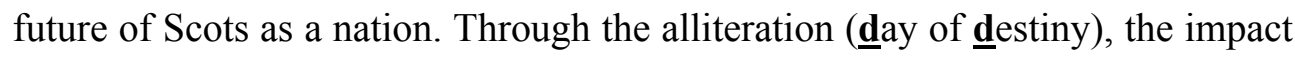
of the forthcoming decision is heightened. Moreover, destiny covertly suggests that Scots have earned a right to decide on their own "fate" (fate and destiny belong to the same semantic field) shape their political, cultural, and even existential future. The image of thistle stands for resilience and the will to endure till the victorious end.

However, it is worth mentioning that there exists a gap in the perceptions of the concepts freedom and independence, with the modernized content of the concepts opposed to their idealized perceptions found in the oral lore. The differences between the perceptions can be traced in the division between Yes and No votes during the Referendum of 2014. The uncertainty about the future of the country, on the one hand, and the issue of the economic impacts of the Independence, on the other, have been the key points of argument of the No vote. The Scottish Sun launched the following headline "Yes or No. Today 
Scotland starts with a blank page" on September 18, 2014. The "Yes or No" dilemma suggests whether Scots want to cast aside their Britishness and stick to their Scottish identity only. On the lexical level, the concept of new Scotland is expressed with the help of the metaphorical phrase "blank page", which can be interpreted as a fresh start for Scots irrespective of the result. The Scottish Daily Record cited a passage from Robert Burns' poem followed by the headline "Choose well Scotland". As was the case in previous headlines, Scotland is personified, thus Scotland as a location and Scots as a nation are inseparable concepts. Scots" right to "choose" their own destiny is also obvious. On the lexical level, the adverb "well" may have a dual interpretation: according to the first interpretation, "well" suggests that Scots should vote both consciously and conscientiously, while the second interpretation is a subtle and implicit prompt to vote for the union with Great Britain. "Well"here may imply as well the generalized common good of Britain and Scotland. The Scottish Daily Express resorts to the reformulation of a popular phrase "The sun never sets on the British Empire", which is modified as "Don't let the sun set on our union." The phrase implicitly states that the union between the two countries dates back to the era of the British Empire and that the two countries have had common history, experience. Furthermore, if "the sun sets on the union" darker times are predicted for both countries that are destined to live side by side.

\section{Conclusion}

The paper demonstrates the relevance of ballads for a study of key cultural and national concepts. The universal concepts love, homeland and freedom are those among the central concepts reflected in Scottish ballads. The analysis of the content of the discussed ballads, as well as the specific means of their materialization made it possible to reveal the cultural features of attitudes toward and interpretations of the concepts and identify the national value system based on them.

The paper also attempted to discuss the relevance of the concept freedom from the historical-cultural perspective. The study of the concept freedom demonstrates that the concept has not lost its significance, however the idealized perception of the freedom has been replaced by a more pragmatic content. The parallel study of the concept freedom in different types of texts created in historically distant period helped track the specific interpretations of the concept, and put the study of the mentioned concepts in a historical-cultural 
context. This issue can be developed further and become an object of a separate study.

\section{References}

Bauman, Z. (2011). From pilgrim to tourist - or a short history of identity. In S. Hall, \& P. du Gay (Eds.), Questions of cultural identity (pp. 18-36). SAGE Publications Ltd, https://www.doi.org/10.4135/9781446221907.n2 Dekavalla, M. (2016). The Scottish press account: narratives of the independence referendum and its aftermath. In N. Blain, D. Hutchinson, \& G. Hassan (Eds.), Scotland's referendum and the media: National and international perspectives (pp. 46-58). Edinburgh: Edinburgh University Press, https://www.doi.org/10.3366/edinburgh/9780748696581.003.0005

Engstrom, R. (2019). The 2014 Scottish independence referendum in text image and thought. Linnaeus University Press: Holmbergs.

Gerould, G. (1957). The ballad of tradition. New York: Oxford University Press.

Karasik, V.I. (2004). Jazykovoy krug: lichnost', koncepty, diskurs [Language circle: identity, concept, discourse]. Moscow: Gnozis.

Kolesov, V., \& Pimenova, M. (2012). Konceptologia. [Conceptology]. Kemerovo: Kemerovskiy gosudarstveniy universitet.

Maslova, V.A. (2004). Vvedenie v kognitivnuyu lingvistiku [Introduction to cognitive linguistics]. Moscow: Nauka.

McCrone, D. (2005). Understanding Scotland: the sociology of a nation. New York: Taylor \& Francis.

Mitchell, J. (2014). The Scottish question. Oxford: Oxford University Press

Popova, Z.D., \& Sternin, I.A. (2007). Kognitivnaya lingvistika [Cognitive linguistics]. Moscow: ACT: Vostok-Zapad.

Sternin, I.A. (1984). O viyavlenii nacional'no-kul'turnoy specifiki semantiki slova [On the influence of the national-cultural specifics of a word semantics] In Nacional'noe i internacional'noe v razvitii yazykov (pp. 310). Ivanovo: Izd-vo IGHTI.

Vorkachev, S. (2003). Sopostavitelnaya etnosemantica teleonomnykh konceptov "lyubov" $i$ "schastye" (russko-angliyskie paralleli) [Comparative ethnosemantics of teleonomic concepts "love" and "happiness"]. Volgograd: Peremena.

Vorkachev, S., Kuznetsova, L., Kusov, G., Polinichenko, Yu., \& Khizova, M. (2007). Lingvokulturniy koncept: tipologiya i oblasti bytovaniya [Linguo- 
cultural concept: Typology and spheres of existence].Volgograd:

Volgogradskiy gosudarstvenniy unuversitet.

Wierzbicka, A. (1992). Semantics, culture, and cognition: Universal human concepts in culture-specific configurations. New York: Oxford University Press.

\section{Sources of Data}

A Ballad for Douglas Young. (n.d.). Retrieved February 13, 2021, from https://electricscotland.com/culture/features/scots/douglas_young.htm

Chambers, R. (1829). The Scottish songs: collected and illustrated by Robert

Chambers. Retrieved February 13, 2021, from https://archive.org/details/scottishsongscol01chamuoft

Duffy, E. (2020, September 18). Scottish independence: front pages of newspaper on 2014 results day. The Herald. Retrieved January 12, 2021, from http://www.heraldscotland.com

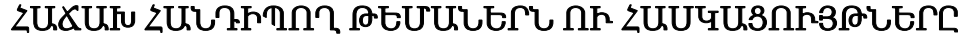

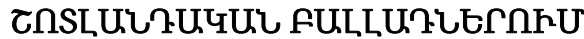

\section{Unłhqł Uunnjuqu}

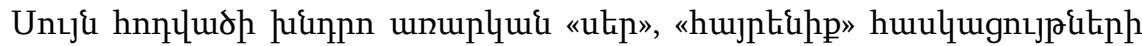

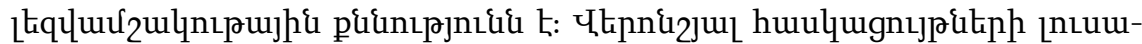

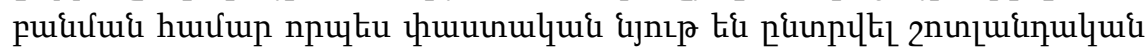

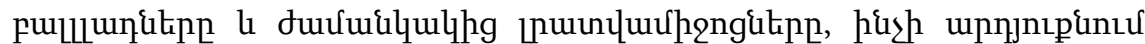

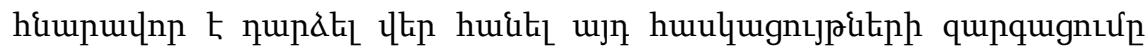

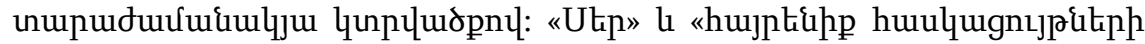

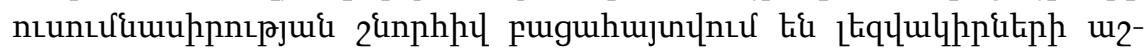

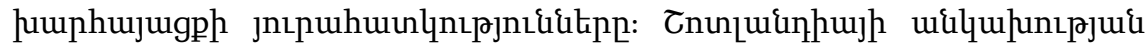

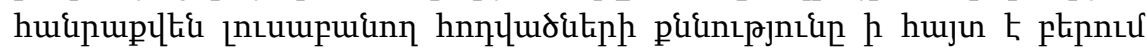

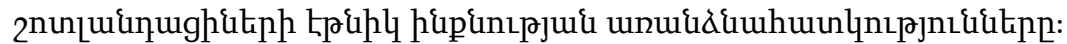

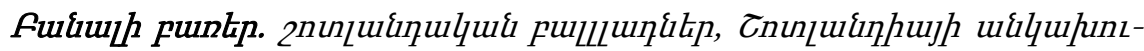

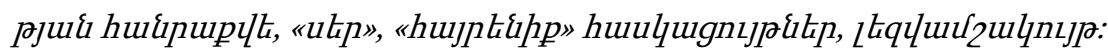

